\title{
Detection of enterotoxin gene (sea) and biofilm formation ability among multi- drug resistant Staphylococcus aureus isolated from shawarma sandwich sold at selected kiosks in Klang Valley, Malaysia
}

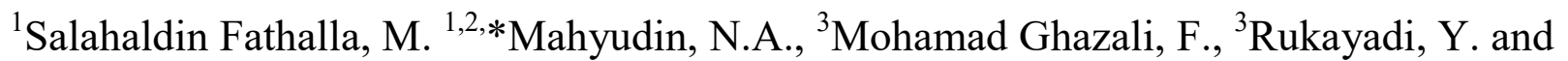 \\ ${ }^{4}$ Jaafar, S.N. \\ ${ }^{I}$ Department of Food Service and Management, Faculty of Food Science and Technology, \\ Universiti Putra Malaysia, 43400 UPM Serdang, Selangor, Malaysia \\ ${ }^{2}$ Halal Products Research Institute, Universiti Putra Malaysia, 43400 UPM Serdang, Selangor, Malaysia \\ ${ }^{3}$ Department of Food Science, Faculty of Food Science and Technology, Universiti Putra Malaysia, 43400 \\ UPM Serdang, Selangor, Malaysia \\ ${ }^{4}$ School of Food Science and Technology, Universiti Malaysia Terengganu, 21030 Kuala Terengganu,
} Terengganu, Malaysia

\section{Article history: \\ Received: 30 January 2020 \\ Received in revised form: 14 March 2020 \\ Accepted: 22 March 2020 \\ Available Online: 16 April 2020}

\section{Keywords:}

Biofilm formation,

Multidrug resistance,

Staphylococcus aureus,

sea genes,

Shawarma

\section{DOI:}

https://doi.org/10.26656/fr.2017.4(4).039

\begin{abstract}
The occurrence of multi-drug resistant Staphylococcus aureus in food product of animal origin has increased the concern about their spread into the food supply chain. Presence of multidrug-resistant $S$. aureus in food products, including ready-to-eat foods imposes potential hazard for consumers. The objective of this research was to investigate the presence of multi-drug resistance of $S$. aureus in sixty ready-to-eat shawarma sandwiches. Agar-disc diffusion assay determined their resistance to 11 antibiotics. The sea and sed enterotoxin genes were detected by polymerase chain reaction method. Biofilm formation potential (BFP) was quantified by microtitre plate assay. The result revealed that thirty-six samples $(60 \%)$ were positive for $S$. aureus. Majority of the isolates $(\mathrm{n}=29 ; 80.6 \%)$ were resistant to at least one antibiotic. The isolates demonstrated highest resistance against ampicillin (69.4\%) and penicillin (69.4\%), while resistance to ciprofloxacin, tetracycline and kanamycin were $47.2 \%, 33.3 \%$ and $22.2 \%$, respectively. Several isolates were resistant to trimethoprim (5.6\%), trimethoprim-sulfamethoxazole- $(2.8 \%)$, gentamicin $(2.8 \%)$ and cephalothin $(2.8 \%)$, while none exhibited resistance to chloramphenicol and nitrofurantoin. Out of the thirty-six isolates, twelve isolates (33.3\%) were resistant to three or more classes of antibiotic (multidrug-resistant) and 50\% had a Multiple Antibiotic Resistance index value more than 0.25 . Of the multi-drug resistant isolates, four were positive for sea genes but no sed genes were present. All multi-drug resistance isolates were biofilm formers with five and six isolates were strong and moderate formers, respectively. Additionally, all the sea gene carrying multi-drug resistance isolates were strong biofilm formers. These findings revealed shawarma as a potential vehicle for the spread of multidrug-resistant $S$. aureus, suggesting more control measures for ready-to-eat food.
\end{abstract}

\section{Introduction}

Shawarma sandwiches are served in several fastfood restaurants in Europe, the Middle East, Canada, and most recently in Malaysia. Shawarma's origin can be traced back to Turkey, and to the Turkish word "çevirme" meaning to rotate (Sirkeci, 2016). It is however known in various countries by various names including chawarma, doner kebab, donair, and gyro (Ayaz et al., 1985; Todd et al., 1986; Nimri et al., 2014).
Shawarma is a famous sandwich made of chicken, lamb, or beef. The majority of restaurants serving shawarma use the breasts of chicken, as these cuts are cheaper and more easily digestible than red meat (Kayaardi et al, 2006).

Shawarma is mostly popular as street food, so it is at risk of contamination by food pathogens from the environment. Among the major problems facing developing nations including Malaysia are foodborne 
infections caused by microbial agents, likely occurring as a result of a change in decision-making involving the production, consumption, and storage of food brought about by the liberation and globalization of trade and the increased importance of food (Satcher, 2000; Abdelgadir et al., 2009; Shafizi et al., 2016). In previous study, an increasing incidence of foodborne infections had been observed in Malaysia between 2005 and 2008 (Rahman, 2019). Nevertheless, death rates due to these foodborne infections have reportedly remained the same with an equivalent rate of mortality to that obtained in 2008 (Abdul-Mutalib et al., 2012). Additionally, in 2006, 3625 food premises out of a total available of 81,686 were shut down because they did not meet the requirements of the Food Act 1983, Section II, as enforced by the relevant authority $(\mathrm{MOH}, 2006$; Sani et al., 2014). The foodborne infections in Malaysia can mainly be traced to unhygienic food handling procedures, which contribute to $50 \%$ of the cases $(\mathrm{MOH}, 2007)$.

Shawarma is a food that can potentially become contaminated with pathogenic bacteria during preparation and processing. Studies analyzing the pathogen contamination of shawarma in various countries revealed that the shawarma had high contamination of several microbes and certain foodborne pathogens that were multidrug-resistant including $S$. aureus (Harakeh et al., 2005; Odu and Akano, 2012; Abdalhamid et al., 2013; Nimri et al., 2014; Salem et al., 2016).

S. aureus is one of the most vital species of bacteria in food microbiology and has long been regarded as a potential threat to foodborne illnesses. It colonizes human skin and the front nares in a substantial fraction of the human population (Kluytmans et al., 2005; Castro et al., 2016). Some of these pathogens are resistant to antimicrobials including the commonly used classes of antibiotics (Sharaf et al., 2012; Nimri et al., 2014; Bantawa et al., 2019).

The main threat of food contamination to general public health stems from bacteria that are resistant to antibiotics since the determinants of the resistance could be transferred to other bacterial pathogens in food. Several reports have shown the occurrence of foodborne pathogenic microbes that are resistant to antimicrobials (Sharaf et al., 2012; Nimri et al., 2014).

S. aureus is able to produce heat-stable enterotoxins responsible for several diseases (Bergdoll, 1983). There are five serological staphylococcal classical antigens identified including staphylococcal enterotoxins (SE) A, $\mathrm{B}, \mathrm{C}, \mathrm{D}$ and $\mathrm{E}$ out of which SEA and SED a responsible for about $95 \%$ of the global incidence of staphylococcal food poisoning (Sezer et al., 2015). The most common toxin detected in outbreaks of food poisoning in the United States was the SEA with almost $77 \%$ occurrence, followed by SED with $38 \%$ and SEB with $10 \%$. SEA is the most commonly found enterotoxin among SFD outbreaks in Japan, France, and UK (Balaban and Rasooly, 2000; Argudín et., 2010).

To the best of the author's knowledge, the current study is the first to determine the occurrence of multidrug-resistant $S$. aureus from chicken shawarma in Arabic kiosks in Malaysia. It further aims to investigate the prevalence of antimicrobial resistance in the isolates against some commonly used antibiotics. The findings of this research will provide the necessary information for relevant authorities to manage public health threats associated with the consumption of shawarma sandwiches.

\section{Materials and methods}

\subsection{Sample collection}

A total of sixty shawarma samples were purchased from kiosks at Arabic restaurants $(n=20)$ in the Klang Valley area, Malaysia. The samples were obtained from three visits to each kiosk in the periods of July 2016 to Mac 2017. Samples were collected in a sterile plastic bag and kept in an icebox $\left(4-8^{\circ} \mathrm{C}\right)$ immediately after collection and transported to the laboratory within 4 hours.

\subsection{Sample processing}

Shawarma sandwich samples were cut into smaller pieces using a sterile knife and $25 \mathrm{~g}$ of the samples were mixed with $225 \mathrm{~mL}$ of sterile buffered peptone water (Oxoid, United Kingdom) in a stomacher bag and homogenized for $60 \mathrm{~s}$ using a Stomacher Lab-Blender 400 (Seward Medical, UK). The homogenized samples were incubated overnight at $37^{\circ} \mathrm{C}$.

\subsection{Isolation and identification of Staphylococcus aureus}

An aliquot of $0.1 \mathrm{~mL}$ of the homogenized sample was spread onto a Baird-Parker agar (BPA) medium (Himedia, India) supplemented with Egg Yolk Tellurite Emulsion (Himedia, India). After incubated at $37^{\circ} \mathrm{C}$ for $24 \mathrm{hrs}$, a typical colony (black/dark gray colony surrounded by an opaque halo) was selected and subjected to Gram Staining, catalase test and coagulase reactions (Lancette and Tatini, 1992). The suspected $S$. aureus colonies were further tested by PCR for confirmation using specific primer pairs of nuc gene (Integrated DNA Technologies, Inc., Coralville, IA, USA) with the forward sequence of 5'GCGATTGATGGTGATACGGTT-3' and reverse sequence of 5'-AGCCAAGCCTT GACGAACTAAAGC 
-3' (Brakstad et al., 1992; Kuźma et al., 2003; Yang et al., 2007). These primers amplify $270 \mathrm{bp}$ region of $n u c$ gene fragment of $S$. aureus. A total of $25 \mu \mathrm{L}$ reaction mixture was prepared for the amplification and it contained $1 \mu \mathrm{L}$ of $50 \mathrm{ng}$ of the genomic DNA, $1 \mu \mathrm{L}$ each of $10 \mu \mathrm{M}$ of the forward and reverse primers, $12.5 \mu \mathrm{l}$ of 2x PCRBIO Taq Mix Red (PCR Biosystems Ltd, London, UK) and finally made up to $25 \mu \mathrm{L}$ with sterile distilled water. The amplification was performed in a thermal cycler (Kyratec Super Cycler Thermal Cycler, Australia) with the following conditions: initial denaturation at $95^{\circ} \mathrm{C}$ for 10 mins followed by 37 cycles of denaturation at $94^{\circ} \mathrm{C}$ for $60 \mathrm{~s}$, annealing at $55^{\circ} \mathrm{C}$ for $30 \mathrm{~s}$, extension at $72^{\circ} \mathrm{C}$ for $90 \mathrm{~s}$ and a final extension $72^{\circ}$ $\mathrm{C}$ for 5 mins. S. aureus ATCC 13565 was used as a positive control in this experiment. For PCR products visualization, $5 \mu \mathrm{L}$ of the PCR products were loaded onto an ethidium bromide-stained $1.5 \%$ agarose gel for electrophoresis and visualization of the amplified PCR products. The amplicons were then measured at $270 \mathrm{bp}$ using Gelpilot 100 bp DNA ladder (Qiagen, Hilden, Germany).

\subsection{Antimicrobial susceptibility testing}

Susceptibility of all the $S$. aureus isolates to antimicrobials was determined by an agar diffusion test using commercially available antibiotic disks (Oxoid, United Kingdom) as described by the Clinical Laboratory Standards Institute (CLSI) guidelines (CLSI, 2017). An overnight Mueller Hinton broth (MHB) (Merck, Germany) culture of the test isolate (0.5 McFarland) was spread on a Mueller Hinton Agar (MHA) (Merck, Germany) plate. Antibiotic discs were evenly dispensed on the inoculated MHA plates and incubated at $37^{\circ} \mathrm{C}$ for $18-24 \mathrm{hrs}$. Eleven types of antibiotics used were Penicillin $(10 \mu \mathrm{g})$, Ampicillin (10 $\mu \mathrm{g})$, Gentamicin $(10 \mu \mathrm{g})$, Kanamycin $(30 \mu \mathrm{g})$, Tetracycline $(30 \mu \mathrm{g})$, Chloramphenicol $(30 \mu \mathrm{g})$, Trimethoprim $(5 \mu \mathrm{g})$, Sulfamethoxazole-Trimethoprim $(25 \mu \mathrm{g})$, Ciprofloxacin $(5 \mu \mathrm{g})$, Cephalothin $(30 \mu \mathrm{g})$, and Nitrofurantoin $(300 \mu \mathrm{g})$. After incubation, the diameter of the inhibition zone was measured. Antibiotic susceptibility profile was determined based on the CLSI standard (CLSI, 2017). The resistance of a single isolate to three or more classes of antibiotics (Oteo et al., 2005; Geidam et al., 2012) was characterized as multidrug resistance (MDR). The values of multiple antibiotic resistance (MAR) index were calculated as the ratio of number of antibiotics to which the organisms were resistant to the total number of antibiotics to which the organisms were exposed and is mathematically represented thus;

$$
\mathrm{MAR}=\mathrm{A} / \mathrm{B}
$$

Where $\mathrm{A}=$ the total number of antibiotics to which the organism is resistant, and $\mathrm{B}=$ the total number of antibiotics to which the organism was exposed

The MAR index is an important tool for the assessing the health risks that aids in identifying an isolate originating from a region excessive usage of the antibiotic (Davis and Brown, 2016). Values of MAR index greater than 0.2 are considered an important indicator for assessing the contamination risk (Krumperman, 1983).

\subsection{Detection of enterotoxin genes (sea and sed)}

Primers employed for SEA detection consisted the forward 5'-CCT TTG GAA ACG GTT AAA ACG-3' and the reverse 5'-TCT GAA CCT TCC CAT CAA AAA C-3' with estimated amplicon size of $127 \mathrm{bp}$, while primers used for SED detection consisted of the forward 5'-CTA GTT TGG TAA TAT CTC CTT TAA ACG-3' and the reverse 5'-TTA ATG CTA TAT CTT ATA GGG TAA ACA TC-3' with estimated amplicon size of 319 bp (Becker et al.,1998). PCR products were prepared in a $25 \mu \mathrm{L}$ reaction volume that consisted of 1 $\mu \mathrm{L}$ of 50ng genomic DNA, $1 \mu \mathrm{L}$ each of $10 \mu \mathrm{M}$ forward and reverse primers, $12.5 \mu \mathrm{L}$ of $2 \mathrm{x}$ PCRBIO Taq Mix Red (PCR Biosystems Ltd, London, UK) which composed of PCRBIO Taq DNA polymerase, $6 \mathrm{mM}$ $\mathrm{MgCl}_{2}$ and $2 \mathrm{mM} \mathrm{dNTPs}$ and $9.5 \mu \mathrm{L}$ sterile distilled water. Amplification of SEA and SED PCR products was carried out in a thermal cycler (Model SC300, Kyratec Australia). The thermal cycler conditions of amplification include; $94^{\circ} \mathrm{C}$ for 5 mins of initial denaturation, 30 cycles of $94^{\circ} \mathrm{C}$ for $1 \mathrm{~min}$ of final denaturation, annealing at $55^{\circ} \mathrm{C}$ for $1 \mathrm{~min}$ and extension at $72^{\circ} \mathrm{C}$ for $1 \mathrm{~min}$. Finally, extension followed at $72^{\circ} \mathrm{C}$ for 5 mins.

\subsection{Biofilm formation}

The biofilm formation ability of all the multi-drug resistant isolates was estimated using the crystal violet staining method described by Beehan (Beehan et al., 2015) with minor modifications. An overnight culture of individual isolate grown in tryptic soy broth (TSB) (Oxoid) at $37^{\circ} \mathrm{C}$ was adjusted to $0.5 \mathrm{McF}$ arland and were diluted in TSB supplemented with $0.25 \%$ glucose (1:40). An aliquot of $200 \mathrm{~mL}$ of the dilutions was dispensed in each well of a sterile polystyrene 96-well microtitre plate (SPL, Life Science, Korea) and the plates were incubated at $37^{\circ} \mathrm{C}$ for $24 \mathrm{hrs}$. Following incubation, the wells were rinsed three times using phosphate buffered saline (PBS; $\mathrm{pH} 7.4 \pm 0.1$; Thermo Fisher Scientific, USA), air-dried for $1 \mathrm{hr}$ at $60^{\circ} \mathrm{C}$ and stained with $0.25 \%$ crystal violet (Thermo Fisher Scientific, USA). The plates were then incubated at $25^{\circ} \mathrm{C}$ for 15 mins and the biofilm formation 
capacity was characterized by measuring the optical density at $\mathrm{OD}_{570 \mathrm{~nm}}$ with a microplate spectrophotometer (Benchmark Plus Microplate Spectrophotometer System, Bio-Rad, USA).

Interpretation of the results of the mean absorbance of the test wells was done in accordance with Stepanović et al. (2000) as non-adherent, weak, moderate or strong biofilm formers on the basis of comparison with the control wells (uninoculated wells) of the plate. Nonadherent were those with absorbance less than or equal to the control wells $\left(\mathrm{OD} \leq \mathrm{OD}_{\mathrm{C}}\right)$; the weakly adherent $\left(\mathrm{OD}_{\mathrm{C}} \leq \mathrm{OD} \leq 2 \mathrm{x} \quad \mathrm{OD}_{\mathrm{C}}\right)$, moderately adherent $\left(2 \mathrm{x} \mathrm{OD}_{\mathrm{C}} \leq\right.$ $\left.\mathrm{OD} \leq 4 \mathrm{x} \quad \mathrm{OD}_{\mathrm{C}}\right)$ and the strongly adherent $\left(4 \mathrm{x} \quad \mathrm{OD}_{\mathrm{C}}<\right.$ OD). Isolates were analyzed for the biofilm in triplicates. Growth medium without bacterial inoculum served as a negative control and S. aureus ATCC 6538 was used as a reference strain.

\section{Results}

\subsection{Detection of Staphylococcus aureus in shawarma} sandwich

Among the total 156 isolates obtained from sixty shawarma samples, thiry-six $(23.1 \%)$ were positive for $S$. aureus (Table 1). More than $25.0 \%$ of the positive $S$. aureus isolates were detected from shawarma sold in nine (9) kiosks namely; R-16 (50.0\%), R-7 (40.0\%), R-6 and R-13 (33.3\%), R-12 (30.0\%), R-2 (28.5\%), R-1, R10 and R-19 (25\%) while the remaining 11 kiosks had lower number of positive isolates $(<25 \%)$.

\subsection{Susceptibility of Staphylococcus aureus to antibiotics}

Table 2 shows that all 36 isolates (100\%) were susceptible to chloramphenicol and nitrofurantoin. The isolates demonstrated highest resistance (69.4\%) against both antibiotics in the Penicillin class; namely ampicillin and penicillin, while resistance to ciprofloxacin, tetracycline and kanamycin were $47.2 \%, 33.3 \%$ and $22.2 \%$, respectively. Only several isolates were resistant to trimethoprim (5.6\%), trimethoprim-sulfamethoxazole (2.8\%), gentamicin (2.8\%) and cephalothin (2.8\%). Intermediate resistance was only observed in 6 isolates $(16.7 \%)$ against kanamycin. Of the 36 isolates, 29 were resistant to at least one (1) antibiotic (see Table 3). Twelve of the 36 isolates (33.3\%) were resistant to three or more classes of antibiotic (MDR) and $50 \%$ had a MAR index value more than 0.25 .

3.3 Characteristic of MDR Isolates of Staphylococcus aureus, the presence of sea and sed genes and their biofilm formation potential

Multidrug resistance associated with enterotoxigenic genes detection and biofilm formation ability is shown in Table 4. The main MDR profiles of the isolates were penicillin- fluoroquinolone-aminoglycosides-tetracycline $(n=6)$, penicillin-fluoroquinolone-tetracycline $(n=2)$ and penicillin-aminoglycosides-tetracycline $(n=2)$. Four of the MDR were positive for sea genes but no sed genes were present in all MDR isolates (Figures 1 and 2). All MDR isolates were able to form biofilm. Five were strong formers, six were moderate and only one with

Table 1 Detection of S. aureus from shawarma sandwich from kiosks $(n=20)$ in Klang Valley, Malaysia.

\begin{tabular}{|c|c|c|c|c|}
\hline Location & Kiosk Code & No. of Sample & No. of Isolate & No. of Positive Isolate (\%) \\
\hline \multirow{5}{*}{ Kajang } & $\mathrm{R}-1$ & 3 & 8 & $2(25.0)$ \\
\hline & R-2 & 3 & 7 & $2(28.5)$ \\
\hline & $\mathrm{R}-3$ & 3 & 10 & $2(20.0)$ \\
\hline & $\mathrm{R}-4$ & 3 & 12 & $2(16.7)$ \\
\hline & $\mathrm{R}-5$ & 3 & 8 & $1(12.5)$ \\
\hline \multirow{5}{*}{ South City } & R-6 & 3 & 6 & $2(33.3)$ \\
\hline & $\mathrm{R}-7$ & 3 & 5 & $2(40.0)$ \\
\hline & R-8 & 3 & 12 & $2(16.7)$ \\
\hline & R-9 & 3 & 11 & $2(18.2)$ \\
\hline & $\mathrm{R}-10$ & 3 & 12 & $3(25.0)$ \\
\hline \multirow{5}{*}{ One South } & $\mathrm{R}-11$ & 3 & 6 & $1(16.7)$ \\
\hline & $\mathrm{R}-12$ & 3 & 10 & $3(30.0)$ \\
\hline & $\mathrm{R}-13$ & 3 & 9 & $3(33.3)$ \\
\hline & $\mathrm{R}-14$ & 3 & 6 & $1(16.7)$ \\
\hline & $\mathrm{R}-15$ & 3 & 6 & $1(16.7)$ \\
\hline \multirow{5}{*}{$\begin{array}{l}\text { Kuala } \\
\text { Lumpur }\end{array}$} & $\mathrm{R}-16$ & 3 & 2 & $1(50.0)$ \\
\hline & $\mathrm{R}-17$ & 3 & 9 & $2(22.2)$ \\
\hline & $\mathrm{R}-18$ & 3 & 5 & $1(22.2)$ \\
\hline & R-19 & 3 & 8 & $2(25.0)$ \\
\hline & R-20 & 3 & 4 & $1(25.0)$ \\
\hline Total & & 60 & 156 & $36(23.1)$ \\
\hline
\end{tabular}


Table 2. Antibiotic resistance profile of $S$. aureus isolates obtained from shawarma sandwiches $(\mathrm{n}=60)$.

\begin{tabular}{ccccc}
\hline Class of Antibiotics & Antibiotic (ug)* & Resistant (\%) & Intermediate (\%) & Susceptible (\%) \\
\hline & AMP & $25(69.4)$ & - & $11(30.5)$ \\
Penicillin & P & $25(69.4)$ & - & $11(30.5)$ \\
Fluoroquinolone & CIP & $17(47.2)$ & - & $19(52.7)$ \\
& CN & $1(2.8)$ & - & $35(97.2)$ \\
Aminoglycosides & K & $8(22.2)$ & $6(16.7)$ & $22(61.1)$ \\
Cephem & KF & $1(2.8)$ & - & $35(97.2)$ \\
Tetracycline & TE & $12(33.3)$ & - & $24(66.7)$ \\
Folate pathway & W & $2(5.6)$ & - & $34(94.4)$ \\
inhibitor & SXT & $1(2.8)$ & - & $35(97.2)$ \\
Phenicol & $\mathrm{C}$ & - & - & $36(100)$ \\
Nitrofurantoin & $\mathrm{F}$ & - & - & $36(100)$ \\
\hline
\end{tabular}

* $\mathrm{AMP}=$ ampicillin, $\mathrm{P}=$ penicillin $\mathrm{G}, \mathrm{CIP}=$ ciprofloxacin, $\mathrm{CN}=$ gentamicin, $\mathrm{K}=$ kanamycin, $\mathrm{KF}=$ cephalothin, $\mathrm{TE}=$ tetracycline, $\mathrm{W}=$ trimethoprim, $\mathrm{SXT}=$ trimethoprim-sulfamethoxazole, $\mathrm{C}=$ chloramphenicol, $\mathrm{F}=$ nitrofurantoin.

Table 3. Multiple antimicrobial resistance (MAR) index value of $S$. aureus isolates.

\begin{tabular}{|c|c|c|c|}
\hline Isolate & Antibiotic resistant profile* & No. of antibiotics** & MAR Index*** \\
\hline $\mathrm{S} 1.1$ & P AMP W & $3(2)$ & 0.27 \\
\hline $\mathrm{S} 1.2$ & P AMP & $2(1)$ & 0.18 \\
\hline S 2.2 & CIP & $1(1)$ & 0.09 \\
\hline S2.1 & CIP & $1(1)$ & 0.09 \\
\hline S3.1 & P AMP CIP & $3(2)$ & 0.27 \\
\hline S3.2 & P AMP CIP TE & $4(3)$ & 0.36 \\
\hline S4.1 & P AMP CIP TE K & $5(4)$ & 0.45 \\
\hline S4.2 & P AMP CIP TE K & $5(4)$ & 0.45 \\
\hline S5.1 & - & - & - \\
\hline S6.1 & P AMP CIP KF CN & $5(4)$ & 0.45 \\
\hline S6.2 & P AMP & $2(1)$ & 0.18 \\
\hline S7.1 & P AMP & $2(1)$ & 0.18 \\
\hline S7.2 & P AMP & $2(1)$ & 0.18 \\
\hline S8.1 & - & - & - \\
\hline S8.2 & P AMP CIP TE K & $5(4)$ & 0.45 \\
\hline S9.1 & - & - & - \\
\hline S9.2 & P AMP CIP TE K & $5(4)$ & 0.45 \\
\hline S10.1 & P AMP TE K & $4(3)$ & 0.36 \\
\hline $\mathrm{S} 10.2$ & P AMP CIP TE K & $5(4)$ & 0.45 \\
\hline S10.3 & P AMP & $2(1)$ & 0.18 \\
\hline S11.1 & - & - & - \\
\hline $\mathrm{S} 12.1$ & - & - & - \\
\hline S12.2 & - & - & - \\
\hline $\mathrm{S} 12.3$ & P AMP CIP & $3(2)$ & 0.27 \\
\hline S13.1 & P AMP & $2(1)$ & 0.18 \\
\hline $\mathrm{S} 13.2$ & P AMP TE K & $4(3)$ & 0.36 \\
\hline S13.3 & P AMP CIP TE & $4(3)$ & 0.36 \\
\hline S14.1 & P AMP CIP & $3(2)$ & 0.27 \\
\hline $\mathrm{S} 15.1$ & P AMP & $2(1)$ & 0.18 \\
\hline S16.1 & - & - & - \\
\hline S17.1 & P AMP CIP & $3(2)$ & 0.27 \\
\hline S17.3 & P AMP TE & $3(2)$ & 0.27 \\
\hline S18.3 & CIP SXT W TE K & $5(4)$ & 0.45 \\
\hline S19.1 & P AMP CIP TE K & $5(4)$ & 0.45 \\
\hline S19.3 & CIP & $1(1)$ & 0.09 \\
\hline $\mathrm{S} 20.2$ & P AMP & $2(1)$ & 0.18 \\
\hline
\end{tabular}

$\mathrm{AMP}=$ ampicillin, $\mathrm{P}=$ penicillin $\mathrm{G}, \mathrm{CIP}=$ ciprofloxacin, $\mathrm{CN}=$ gentamicin, $\mathrm{K}=$ kanamycin, $\mathrm{KF}=$ cephalothin, $\mathrm{TE}=$ tetracycline, $\mathrm{W}=$ trimethoprim, $\mathrm{SXT}=$ trimethoprim-sulfamethoxazole, $\mathrm{C}=$ chloramphenicol, $\mathrm{F}=$ nitrofurantoin.

**The number of antibiotics to which each isolate was resistant. The number in the parenthesis indicates the total number of the classes to which the antibiotics belong.

***Multiple antimicrobial resistances. 
Table 4. Characteristic of MDR isolates of $S$. aureus, the presence of sea and sed genes and their biofilm formation potential

\begin{tabular}{|c|c|c|c|c|c|}
\hline \multirow{2}{*}{ Kiosk code } & \multirow{2}{*}{ Isolate } & \multirow{2}{*}{ MDR profile * } & sea genes & sed genes & Biofilm formation \\
\hline & & & $* *$ & $* *$ & $* * *$ \\
\hline $\mathrm{R}-3$ & SA3.2 & $\begin{array}{l}3 \text { class of antibiotic } \\
(a, b, e)\end{array}$ & + & nd & +++ \\
\hline \multirow{2}{*}{$\mathrm{R}-4$} & SA4.1 & $\begin{array}{l}4 \text { class of antibiotic } \\
(a, b, c, e)\end{array}$ & nd & nd & +++ \\
\hline & SA4.2 & $\begin{array}{l}4 \text { class of antibiotic } \\
\mathrm{a}, \mathrm{b}, \mathrm{c}, \mathrm{e}\end{array}$ & + & nd & +++ \\
\hline $\mathrm{R}-6$ & SA6.1 & $\begin{array}{l}4 \text { class of antibiotic } \\
a, b, c^{*}, d\end{array}$ & nd & nd & ++ \\
\hline $\mathrm{R}-8$ & SA8.2 & $\begin{array}{l}4 \text { class of antibiotic } \\
a, b, c, e\end{array}$ & + & nd & +++ \\
\hline R-9 & SA9.2 & $\begin{array}{l}4 \text { class of antibiotic } \\
a, b, c, e\end{array}$ & nd & nd & ++ \\
\hline \multirow{2}{*}{$\mathrm{R}-10$} & SA10.1 & $\begin{array}{l}3 \text { class of antibiotic } \\
a, c, e\end{array}$ & + & nd & +++ \\
\hline & SA10.2 & $\begin{array}{l}4 \text { class of antibiotic } \\
a, b, c, e\end{array}$ & nd & nd & ++ \\
\hline \multirow{2}{*}{$\mathrm{R}-13$} & SA13.2 & $\begin{array}{l}3 \text { class of antibiotic } \\
a, c, e\end{array}$ & nd & nd & + \\
\hline & SA13.3 & $\begin{array}{l}3 \text { class of antibiotic } \\
a, b, e\end{array}$ & nd & nd & ++ \\
\hline $\mathrm{R}-18$ & SA18.3 & $\begin{array}{l}4 \text { class of antibiotic } \\
b, c, e, f\end{array}$ & nd & nd & ++ \\
\hline $\mathrm{R}-19$ & SA19.1 & $\begin{array}{l}4 \text { class of antibiotic } \\
a, b, c, e\end{array}$ & nd & nd & ++ \\
\hline
\end{tabular}

* multi-drug resistance pattern based on antibiotic class; $a=$ Penicillin, $b=$ Fluoroquinolone, $c=$ Aminoglycosides, $d=$ Cephem, $\mathrm{e}=$ Tetracycline, $\mathrm{f}=$ Folate pathway inhibitor

** genes detected $=+$; genes not detected $=$ nd

$* * *$ biofilm formation; strong $=+++$; moderate $=++$; weak $=+$

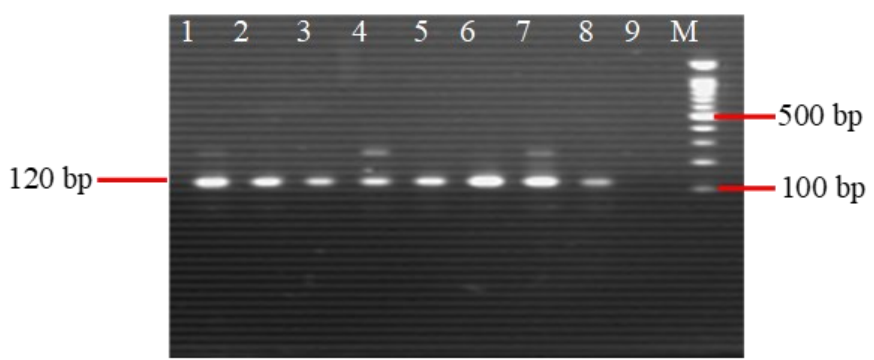

Figure 1. Visualized PCR products of Staphylococcal Enterotoxin A (sea). Lane 1-7= Positive sample (SEA), Lane 8 = Positive control of $S$. aureus ATCC 13565, Lane $9=$ Negative control, Lane $\mathrm{M}=100 \mathrm{bp}$ DNA marker

weak ability. Additionally, all the sea gene-carrying MDR isolates were strong biofilm formers. Moreover, shawarma samples that contained MDR isolates which carried sea genes and with strong biofilm formation ability were detected from four kiosks; namely R-3, R-4, R-8 and R-10.

\section{Discussion}

The occurrence of $S$. aureus in shawarma sandwich in the current study $(60 \%)$ was relatively higher than

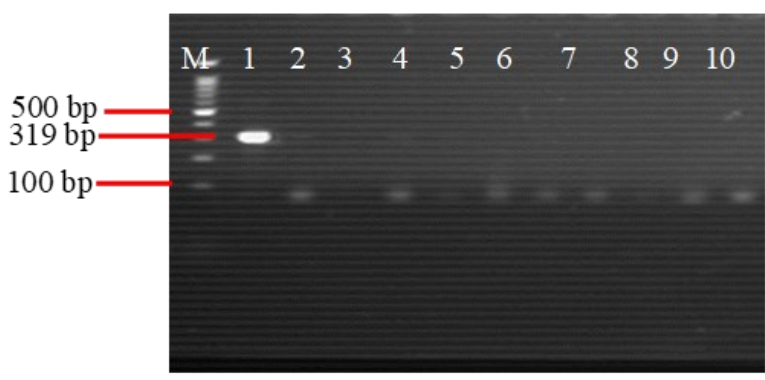

Figure 2. Visualized PCR products of Staphylococcal Enterotoxin D (sed). Lane 2-9= Negative sample (SED), Lane $1=$ Positive control of $S$. aureus ATCC 13565, Lane 10= Negative control, Lane $\mathrm{M}=100$ bp DNA marker

those study reported for various Ready-to-Eat (RTE) foods in Malaysia (Shafizi et al., 2016), China (Song et al., 2015; Yang et al., 2016), Trinidad (Syne et al., 2013), and Bangladesh (Islam et al., 2019), which generally had the occurrence of $S$. aureus. In Sri Lanka, $32.0 \% S$. aureus was found in shawarma and ham (Wimalasekara, 2016).

In this study, the occurrence of $S$. aureus in shawarma samples may be due to three main factors; namely insufficient cooking of chicken meat, 
contamination by raw ingredients and poor hygiene. Raw meat of chicken has been reported contaminated with $S$. aureus (Vazgecer et al., 2004). S. aureus was also found isolated from $75 \%$ chicken and $52 \%$ turkey retail meats (Tang et al., 2017). It was observed during this study that piles of chicken meat were roasted on a rotating skewer, with the outer layer of meat cooked properly, while the inner part within the pile of meat remains raw and juicy. During serving, the outer part of the meat block was shaved, leaving the remaining block of meat to remain heated on the skewer. Based on this cooking method, shawarma samples may contain $S$. aureus cells that survived the method of cooking as roasting chicken meat block on the rotated skewer may cause insufficient or inconsistent cooking of the chicken meat.

Moreover, raw ingredients added to the shawarma; tahini sauce (from the oil of sesame seeds) and vegetables could also be possible sources of contaminants. $S$. aureus was found in vegetables such as cabbage, tomato and lettuce, all were found to have high contamination in ready-to-eat foods including shawarma (Okafor et al., 2003; Meldrum et al., 2009; Sospedra et al., 2013; Faour-Klingbeil et al., 2016). These vegetables may be contaminated with soil that is possibly transmitted to the hands of food handlers, and consequently to the shawarma sandwich (Okafor et al., 2003; Vazgecer et al., 2004; Harakeh et al., 2005; Meldrum et al., 2009; Odu and Akano, 2012).

Food handlers are the key players that prevent food contamination during food preparation by preventing cross-contamination and by using proper cooking methods and storage of cooked food (Soon et al., 2011). This is also supported by random observation by the authors during sample collection in this study, where the majority of the workers in the kiosks did not wear gloves during shawarma preparation and serving. Consequently, the $S$. aureus occurrence in shawarma sandwiches is likely a result of contamination by the food handlers due to their poor hygiene practices. Thus, the contamination of shawarma could be heavily related to the method of preparation, as $S$. aureus is transmitted through sneezing, coughing, and wounds in the hands of food handlers (Odu and Akano, 2012; Abdalhamid et al., 2013; Nimri et al., 2014).

In this study, $80.6 \%$ of $S$. aureus isolates were resistant to at least one antimicrobial, with the substantially higher resistance to the Penicillin class of antibiotic; ampicillin (69.4\%) and penicillin (69.4\%). Similarly, Geidam et al. (2012) found that more than $50 \%$ of the $S$. aureus isolated from the skin of poultry in Malaysia exhibited resistance to penicillin and ampicillin. Similar resistance to penicillin $(53.3 \%)$ and ampicillin $(72.30 \%)$ was observed in $S$. aureus isolated from the food handler's hands in Malaysia (Tan et al., 2014). This result is nearly analogous to that of Arfatahery et al. (2016), who found that all the strains of $S$. aureus isolated from shrimp and fish showed resistance to penicillin and ampicillin. $S$. aureus resistant to penicillin (99.3\%) was also reported in a study investigating dairy products in north-western Greece (Papadopoulos et al., 2018). These results could be due to the fact that antibiotics have been used increasingly for the treatment of bacterial diseases in humans and animals. Several antibiotics, especially for penicillin are generally applied in veterinary medicine (Cháfer-Pericás et al., 2010).

The resistance of the microorganisms to three or more classes of antibiotics considered as multidrugresistant (MDR) (Gibbs et al., 2006; Waters et al., 2011). In this study, twelve isolates were MDR and six of them demonstrated MDR pattern that was dominated by four antibiotic classes (penicillin, fluoroquinolone, aminoglycosides and tetracycline). Multidrug-resistant bacteria are now increasingly common because of the indiscriminate use of antibiotics.

Chickens are possible sources of MDR bacteria because various antibiotics are used to treat infections in chickens and to promote their growth; hence, making it possible for $100 \%$ of isolates from chicken in Oman to exhibit multidrug resistance (Al-Bahry et al., 2007; AlBahry et al., 2015) as compared to an earlier study conducted in Oman in 1986 that reported only 30\% of the isolates being MDR (Al-Bahry, 1999). Multiple drug resistance proves difficult to overcome especially by the commonly used antibiotics and this intensifies the ability of the bacteria to establish themselves in their hosts leading to the production of more virulent factors that enhance their survival (Tan et al., 2014; Frieri et al., 2017).

The Emergence of multiple drug resistance among bacteria from food handlers, food premises and food products has also been a global concern (Altalhi et al., 2010; Ryu et al., 2012; Rasheed et al., 2014; Tan et al., 2014; Melo et al., 2015) and could lead to food poisoning outbreaks that in turn leads to economic loss and loss of lives if people of compromised immunity are involved.

We targeted two classical SEs (sea and sed) genes and found that of the thirty-six $S$. aureus isolates that were resistant to at least one antibiotic, seven (19.4\%) harbored the sea genes. No sed gene was found in any of the isolates tested. The sea gene is the most commonly reported in contaminated foods and also in staphylococcus-related food poisoning cases worldwide 
(Argudín et al., 2010; Gholamzad et al., 2015). A study by Kérouanton et al. (2007) in France on S. aureus linked to food poisoning outbreaks also revealed the highest prevalence of SEA alone and in combination with SED but relatively low percentages $13.9 \%$ and $6.7 \%$ respectively. The presence of $S$. aureus toxins in foods is an indication for the potential to cause food intoxication thereby leading to food poisoning outbreak. Several studies involving the detection of $S$. aureus and its enterotoxins from foods and food products have been conducted worldwide. These include the presence of enterotoxigenic $S$. aureus in ready-to-eat foods in Korea (Kim et al., 2011), retail aquatic food products in China (Rong et al., 2017), goat milk in China (Xing et al., 2016), from food poisoning clone of $S$. aureus in Japan (Sato'o et al., 2014). This study is the first study in Malaysia and therefore there are not sufficient data to make comparisons.

Although the production of sea genes was not investigated in our study, the presence of sea genes carrying $S$. aureus isolates in shawarma samples could be of concern in terms of enterotoxin production. A study on retail foods in China (Wang et al., 2017) reported that more than $90 \%$ of the sea gene carrying $S$. aureus isolates have produced enterotoxins. Considering these MDR isolates which also carry sea gene may enter the food chain, and may be transferred to consumers, their ability to form biofilm was established to evaluate their persistence in the food environment. Our study demonstrated that five of the $12 \mathrm{MDR}$ isolates were strong biofilm formers, and four of these MDR isolates harboured sea genes.

\section{Conflict of interest}

The authors declare no conflict of interest.

\section{Acknowledgement}

The authors would like to thank all the staffs from the Faculty of Food Science and Technology who have been involved throughout the study for all support and assistance.

\section{References}

Abdalhamid, S.A., Farj, A.A. and Ali, A.B. (2013). Bacterial Contamination of Ready to Eat. Foods (shawerma sandwiches), presented at 2nd International Conference on Environment, Agriculture and Food Sciences (ICEAFS), p. 6-7. Misurata City, Libya

Abdelgadir, A.M.M.A., Srivastava, K.K. and Gopal, R.P. (2009). Detection of Listeria monocytogenes in ready to eat meat products. American Journal of
Animal Veterinary Science, 4(4), 101-107. https:// doi.org/10.3844/ajavsp.2009.101.107

Abdul-Mutalib, N.A., Abdul-Rashid, M.F., Mustafa, S., Amin-Nordin, S., Hamat, R.A. and Osman, M. (2012). Knowledge, attitude and practices regarding food hygiene and sanitation of food handlers in Kuala Pilah, Malaysia. Food Control, 27(2), 289293. https://doi.org/10.1016/j.foodcont.2012.04.001

Al-Bahry, S.N. (1999). Antibiotic resistance of Salmonella isolated from Muscat, Oman. Pakistan Journal of Biological Sciences, 2(2), 523-528. https://doi.org/10.3923/pjbs.1999.523.528

Al-Bahry, S.N., El Shafie, A.E., Al Busaidy, S., Al Hinai, J. and Al Shidi, I. (2007). Antibiotic-resistant Salmonella spp. from human and non-human sources in Oman. Eastern Mediterranean Health Journal, 13 (.55-49, (1

Al-Bahry, S.N., Mahmoud, I.Y., Paulson, J.R. and AlMusharafi, S.K. (2015). Antibiotic resistant bacteria in terrestrial and aquatic environments: A review. The International Arabic Journal of Antimicrobial Agents, 4(3), 754. https:// doi.org/10.3823/754

Altalhi, A.D., Gherbawy, Y.A. and Hassan, S.A. (2010). Antibiotic resistance in Escherichia coli isolated from retail raw chicken meat in Taif, Saudi Arabia. Foodborne Pathogens and Disease, 7(3), 281-285. https://doi.org/10.1089/fpd.2009.0365

Arfatahery, N., Davoodabadi, A. and Abedimohtasab, T. (2016). Characterization of Toxin Genes and Antimicrobial Susceptibility of Staphylococcus aureus Isolates in Fishery Products in Iran. Scientific Reports, 6, 34216. https://doi.org/10.1038/srep34216 Argudín, M.Á., Mendoza, M.C. and Rodicio, M.R. (2010). Food poisoning and Staphylococcus aureus enterotoxins. Toxins, 2(7), 1751-1773. https:// doi.org/10.3390/toxins2071751

Ayaz, M., Othman, F.A., Bahareth, T.O., Al-Sogair, A.M. and Sawaya, W.N. (1985). Microbiological quality of shawarma in Saudi Arabia. Journal of Food Protection, 48(9), 811-814. https:// doi.org/10.4315/0362-028X-48.9.811

Balaban, N. and Rasooly, A. (2000). Staphylococcal enterotoxins. International Journal of Food Microbiology, 61(1), 1-10. https://doi.org/10.1016/ S0168-1605(00)00377-9

Bantawa, K., Sah, S.N., Limbu, D.S., Subba, P. and Ghimire, A. (2019). Antibiotic resistance patterns of Staphylococcus aureus, Escherichia coli, Salmonella, Shigella and Vibrio isolated from chicken, pork, buffalo and goat meat in eastern Nepal. BMC Research Notes, 12(1), 1-6. https:// doi.org/10.1186/s13104-019-4798-7 
Becker, K., Roth, R. and Peters, G. (1998). Rapid and specific detection of toxigenic Staphylococcus aureus: use of two multiplex PCR enzyme immunoassays for amplification and hybridization of staphylococcal enterotoxin genes, exfoliative toxin genes, and toxic shock syndrome toxin 1 gene. Journal of Clinical Microbiology, 36(9), 25482553. https://doi.org/10.1128/JCM.36.9.25482553.1998

Beehan, D.P., Wolfsdorf, K., Elam, J., Krekeler, N., Paccamonti, D. and Lyle, S.K. (2015). The evaluation of biofilm-forming potential of Escherichia coli collected from the equine female reproductive tract. Journal of Equine Veterinary Science, 35(11), 935-939. https://doi.org/10.1016/ j.jevs.2015.08.018

Bergdoll, M.S. (1983). Enterotoxins. In Easman, C.S.F. and Adlam, C. (Eds.) Staphylococci and Staphylococcal Infections, p. 559-598. London: Academic Press: London.

Brakstad, O.G., Aasbakk, K. and Mael, J.A. (1992). Detection of Staphylococcus aureus by polymerase chain reaction amplification of the nuc gene. Journal of Clinical Microbiology, 30(7), 1654-1660. https:// doi.org/10.1128/JCM.30.7.1654-1660.1992

Castro, A., Santos, C., Meireles, H., Silva, J. and Teixeira, P. (2016). Food handlers as potential sources of dissemination of virulent strains of Staphylococcus aureus in the community. Journal of Infection and Public Health, 9(2), 153-160. https:// doi.org/10.1016/j.jiph.2015.08.001

Cháfer-Pericás, C., Maquieira, A. and Puchades, R. (2010). Fast screening methods to detect antibiotic residues in food samples. Trends in Analytical Chemistry, 29(9), 1038-1049. https:// doi.org/10.1016/j.trac.2010.06.004

Clinical and Laboratory Standards Institute (CLSI). (2017). Performance Standards of Antimicrobial Susceptibility Testing. $27^{\text {th }}$ ed. CLSI supplement M100. Pennsylvania, USA: CLSI.

Faour-Klingbeil, D., Todd, E.C. and Kuri, V. (2016). Microbiological quality of ready-to-eat fresh vegetables and their link to food safety environment and handling practices in restaurants. LWT-Food Science and Technology, 74, 224-233. https:// doi.org/10.1016/j.lwt.2016.07.051

Frieri, M., Kumar, K. and Boutin, A. (2017). Antibiotic resistance. Journal of Infection and Public Health, 10(4), 369-378. https://doi.org/10.1016/ j.jiph.2016.08.007

Geidam, Y.A., Zakaria, Z., Aziz, S.A., Bejo, S.K., Abu, J. and Omar, S. (2012). High prevalence of multidrug resistant bacteria in selected poultry farms in
Selangor, Malaysia. Asian Journal of Animal and Veterinary Advances, 7(9), 891-897. https:// doi.org/10.3923/ajava.2012.891.897

Gibbs, S.G., Green, C.F., Tarwater, P.M., Mota, L.C., Mena, K.D. and Scarpino, P.V. (2006). Isolation of antibiotic-resistant bacteria from the air plume downwind of a swine confined or concentrated animal feeding operation. Environmental Health Perspectives, 114(7), 1032. https://doi.org/10.1289/ ehp. 8910

Harakeh, S., Yassine, H., Gharios, M., Barbour, E., Hajjar, S., El-Fadel, M. and Tannous, R. (2005). Isolation, molecular characterization and antimicrobial resistance patterns of Salmonella and Escherichia coli isolates from meat-based fast food in Lebanon. Science of the Total Environment, 341 (1), 33-44. https://doi.org/10.1016/ j.scitotenv.2004.09.025

Islam, M.A., Parveen, S., Rahman, M., Huq, M., Nabi, A., Khan, Z.U.M. and Wagenaar, J.A. (2019). Occurrence and characterization of methicillin resistant Staphylococcus aureus in processed raw foods and ready-to-eat foods in an urban setting of a developing country. Frontiers in Microbiology, 2019, 503. https://doi.org/10.3389/ fmicb.2019.00503

Kayaardi, S., Kundakci, A., Kayacier, A. and Gok, V. (2006). Sensory and chemical analysis of doner kebab made from turkey meat. Journal of Muscle Foods, 17(2), 165-173. https://doi.org/10.1111/ j.1745-4573.2006.00040.x

Kérouanton, A., Hennekinne, J.A., Letertre, C., Petit, L., Chesneau, O., Brisabois, A. and De Buyser, M.L. (2007). Characterization of Staphylococcus aureus strains associated with food poisoning outbreaks in France. International Journal of Food Microbiology, 115(3), 369-375. https:// doi.org/10.1016/j.ijfoodmicro.2006.10.050

Kim, N.H., Yun, A.R. and Rhee, M.S. (2011). Prevalence and classification of toxigenic Staphylococcus aureus isolated from refrigerated ready-to-eat foods (sushi, kimbab and California rolls) in Korea. Journal of Applied Microbiology, 111(6), 1456-1464. https:// doi.org/10.1111/j.1365-2672.2011.05168.x

Kluytmans, J.A.J.W. and Wertheim, H.F.L. (2005). Nasal carriage of Staphylococcus aureus and prevention of nosocomial infections. Infection, 33, 3 -8. https://doi.org/10.1007/s15010-005-4012-9

Krumperman, P. H. (1983). Multiple antibiotic resistance indexing of Escherischia coli to identify high-risk sources of fecal contamination of food. Applied and Environmental Microbiology, 46, 165-170. https:// 
doi.org/10.1128/AEM.46.1.165-170.1983

Kuźma, K., Malinowski, E., Lassa, H. and Kłossowska, A. (2003). Specific detection of Staphylococcus aureus by PCR in intramammary infection. Bulletin of the Veterinary Institute in Pulawy, 47, 183-190.

Lancette G.A. and Tatini S.R. (1992). Staphylococcus aureus. In Vanderzant, C. and Splittstoesser, D.F. (Eds.). Compendium of Methods for the Microbiological Examination of Foods. $3^{\text {rd }}$ ed., p. 533-550. Washington, DC, USA: American Public Health Association.

Meldrum, R.J., Little, C.L., Sagoo, S., Mithani, V., McLauchlin, J. and De Pinna, E. (2009). Assessment of the microbiological safety of salad vegetables and sauces from kebab take-away restaurants in the United Kingdom. Food Microbiology, 26(6), 573577. https://doi.org/10.1016/j.fm.2009.03.013

Melo, D.B., Menezes, A.P.D.O., Reis, J.N. and Guimarães, A.G. (2015). Antimicrobial resistance and genetic diversity of Escherichia coli isolated from humans and foods. Brazilian Journal of Microbiology, 46(4), 1165-1170. https:// doi.org/10.1590/S1517-838246420130874

Ministry of Health Malaysia. (2007). Ministry of Health Malaysia Annual report 2007. Putrajaya, Malaysia: Public Health Department, Ministry of Health Malaysia.

Ministry of Health Malaysia. (2006). Annual report 2006. Putrajaya, Malaysia: Public Health Department, Ministry of Health Malaysia.

Nimri, L., AL-Dahab, F.A. and Batchoun, R. (2014). Foodborne bacterial pathogens recovered from contaminated shawarma meat in northern Jordan. The Journal of Infection in Developing Countries, 8(11), 1407-1414. https:// doi.org/10.3855/jidc. 4368

Odu, N.N. and Akano, U.M. (2012). The microbiological assessment of ready-to-eat food (Shawarma) in Port Harcourt City, Nigeria. Nature and Science, 10(8), 18.

Okafo, C.N., Umoh, V.J. and Galadima, M. (2003). Occurrence of pathogens on vegetables harvested from soils irrigated with contaminated streams. Science of the Total Environment, 311(1), 49-56. https://doi.org/10.1016/S0048-9697(03)00057 $-3$

Oteo, J., Lázaro, E., de Abajo, F.J., Baquero, F. and Campos, J. (2005). Antimicrobial-resistant invasive Escherichia coli, Spain. Emerging Infectious Diseases, 11(4), 546. https://doi.org/10.3201/ eid1104.040699

Papadopoulos, P., Papadopoulos, T., Angelidis, A.S.,
Boukouvala, E., Zdragas, A., Paapa, A. and Sergelidis, D. (2018). Prevalence of Staphylococcus aureus and of methicillin-resistant S. aureus (MRSA) along the production chain of dairy products in north-western Greece. Food Microbiology, 69, 43-50. https://doi.org/10.1016/ j.fm.2017.07.016

Rahman, M.H.A. (2019). A Study on Causal Relationship between Food Handler's Awareness and Safe Food Handling Practices in Malaysia. Politeknik and Kolej Komuniti Journal of Social Sciences and Humanities, 4(1), 145-162.

Rasheed, M.U., Thajuddin, N., Ahamed, P., Teklemariam, Z. and Jamil, K. (2014). Antimicrobial drug resistance in strains of Escherichia coli isolated from food sources. Revista do Instituto de Medicina Tropical de São Paulo, 56(4), 341-346. https:// doi.org/10.1590/S0036-46652014000400012

Rong, D., Wu, Q., Xu, M., Zhang, J. and Yu, S. (2017). Prevalence, virulence genes, antimicrobial susceptibility, and genetic diversity of Staphylococcus aureus from retail aquatic products in China. Frontiers in Microbiology, 2017, 714. https://doi.org/10.3389/fmicb.2017.00714

Ryu, S.H., Lee, J.H., Park, S.H., Song, M.O., Park, S.H., Jung, H.W. and Park, S.G. (2012). Antimicrobial resistance profiles among Escherichia coli strains isolated from commercial and cooked foods. International Journal of Food Microbiology, 159(3), 263-266. https:// doi.org/10.1016/j.ijfoodmicro.2012.09.001

Salem, N.I., El Gamel, A.M., Khalifa, A., Abd-El-Hady, H.A. and AbouZeid, M.A. (2016). Microbial Status of Shawerma Sandwiches in Kafr El-Sheikh Governorate. Alexandria Journal for Veterinary Sciences, 51(2), 303-309. https://doi.org/10.5455/ ajvs. 238905

Sani, N.A. and Siow, O.N. (2014). Knowledge, attitudes and practices of food handlers on food safety in food service operations at the Universiti Kebangsaan Malaysia. Food Control, 37, 210-217. https:// doi.org/10.1016/j.foodcont.2013.09.036

Satcher, D. (2000). Food safety: a growing global health problem. Journal of the American Medical Association, 283(14), 1817-1817. https:// doi.org/10.1001/jama.283.14.1817

Sato'o, Y., Omoe, K., Naito, I., Ono, H. K., Nakane, A., Sugai, M., Yamagishi, N. and Hu, D.L. (2014). Molecular epidemiology and identification of a Staphylococcus aureus clone causing food poisoning outbreaks in Japan. Journal of Clinical Microbiology, 52, 2637-2640. https:// doi.org/10.1128/JCM.00661-14 
Sezer, Ç., Özgür, Ç., Aksem, A. and Leyla, V. (2015). Food Handlers: a bridge in the journey of enterotoxigenic MRSA in Food. Journal für Verbraucherschutz und Lebensmittelsicherheit, 10 (2), 123-129. https://doi.org/10.1007/s00003-0150939-7

Shafizi, A.W., Ridzuan, M., Ubong, A., New, C.Y., Mohhiddin, O., Toh, P.S. and Son, R. (2016). Assessing Staphylococcus aureus in ready to eat (RTE) food and risk assessment of food premises in Putrajaya. International Food Research Journal, 23 (4), 1761-1766.

Sharaf, E.M. and Sabra, M.S. (2012). Microbiological loads for some types of cooked chicken meat products at Al-Taif Governorate, KSA. World Applied Sciences Journal, 17(5), 593-597.

Sirkeci, I. (2016). Transnational Döner Kebab taking over the UK. Transnational Marketing Journal, 4(2), 143-158. https://doi.org/10.33182/tmj.v4i2.397

Song, M., Bai, Y., Xu, J., Carter, M. Q., Shi, C. and Shi, X. (2015). Genetic diversity and virulence potential of Staphylococcus aureus isolates from raw and processed food commodities in Shanghai. International Journal of Food Microbiology, 195, 1-8. https://doi.org/10.1016/ j.ijfoodmicro.2014.11.020

Soon, J. M., Singh, H. and Baines, R. (2011). Foodborne diseases in Malaysia: A review. Food Control, 22(6), 823-830. https://doi.org/10.1016/ j.foodcont.2010.12.011

Sospedra, I., Rubert, J., Soriano, J.M. and Mañes, J. (2013). Survey of microbial quality of plant-based foods served in restaurants. Food Control, 30(2), 418 -422. https://doi.org/10.1016/j.foodcont.2012.08.004

Stepanović, S., Vuković, D., Dakić, I., Savić, B. and Švabić-Vlahović, M. (2000). A modified microtiterplate test for quantification of staphylococcal biofilm formation. Journal of Microbiological Methods, 40 (2), 175-179. https://doi.org/10.1016/S0167-7012 (00)00122-6

Syne, S. M., Ramsubhag, A. and Adesiyun, A.A. (2013). Microbiological hazard analysis of ready-to-eat meats processed at a food plant in Trinidad, West Indies. Infection Ecology and Epidemiology, 3(1), 20450. https://doi.org/10.3402/iee.v3i0.20450

Tan, S.L., Lee, H.Y. and Mahyudin, N.A. (2014). Antimicrobial resistance of Escherichia coli and Staphylococcus aureus isolated from food handler's hands. Food Control, 44, 203-207. https:// doi.org/10.1016/j.foodcont.2014.04.008

Tang, Y., Larsen, J., Kjeldgaard, J., Andersen, P.S., Skov, R. and Ingmer, H. (2017). Methicillin-resistant and-susceptible Staphylococcus aureus from retail meat in Denmark. International Journal of Food Microbiology, 249, 72-76. https://doi.org/10.1016/ j.ijfoodmicro.2017.03.001

Todd, E.C., Szabo, R. and Spiring, F. (1986). Donairs (gyros)-potential hazards and control. Journal of Food Protection, 49(5), 369-377. https:// doi.org/10.4315/0362-028X-49.5.369

Vazgecer, B., Ulu, H. and Oztan, A. (2004). Microbiological and chemical qualities of chicken döner kebab retailed on the Turkish restaurants. Food Control, 15(4), 261-264. https:// doi.org/10.1016/S0956-7135(03)00065-3

Wang, W., Baloch, Z., Jiang, T., Zhang, C., Peng, Z., Li, F. and $\mathrm{Xu}, \mathrm{J}$. (2017). Enterotoxigenicity and antimicrobial resistance of Staphylococcus aureus isolated from retail food in China. Frontiers in Microbiology, 2017, 2256. https://doi.org/10.3389/ fmicb.2017.02256

Waters, A.E., Contente-Cuomo, T., Buchhagen, J., Liu, C.M., Watson, L., Pearce, K. and Keim, P. S. (2011). Multidrug-resistant Staphylococcus aureus in US meat and poultry. Clinical Infectious Diseases, 52 (10), 1227-1230. https://doi.org/10.1093/cid/cir181

Wimalasekara, S.G.M.R.L. and Gunasena, G.D.D.K (2016). Microbiological quality of ready-to-eat meat -based food available in temporary food outlets in Gall Face Green, Colombo, Sri Lanka. International Journal of Agriculture, Forestry and Plantation, 4, $38-44$.

Xing, X., Zhang, Y., Wu, Q., Wang, X., Ge, W. and Wu, C. (2016). Prevalence and characterization of Staphylococcus aureus isolated from goat milk powder processing plants. Food Control, 59, 644650. https://doi.org/10.1016/j.foodcont.2015.06.042

Yang, X., Zhang, J., Yu, S., Wu, Q., Guo, W., Huang, J. and Cai, S. (2016). Prevalence of Staphylococcus aureus and methicillin-resistant Staphylococcus aureus in retail ready-to-eat foods in China. Frontiers in Microbiology, 2016, 816. https:// doi.org/10.3389/fmicb.2016.00816

Yang, Y., Su, X.D., Yuan, Y.W., Kang, C.Y., Li, Y.J. and Zhong, X.Y. (2007). Detection of Staphylococcus aureus in dairy products by polymerase chain reaction assay. Agricultural Sciences in China, 6(7), 857-862. https:// doi.org/10.1016/S1671-2927(07)60122-9

Zhang, S., Iandolo, J.J. and Stewart, G.C. (1998). The enterotoxin D plasmid of Staphylococcus aureus encodes a second enterotoxin determinant (sej). FEMS Microbiology Letters, 168(2), 227-233. https://doi.org/10.1111/j.1574-6968.1998.tb13278.x 